\title{
Interleukin-8 gene polymorphism and susceptibility to gastric cancer in a brazilian population
}

\author{
Aledson V. Felipe ${ }^{1}$, Tiago D. Silva ${ }^{1}$, Célia A. Pimenta ${ }^{1}$, Paulo Kassab ${ }^{2}$, Nora M. Forones ${ }^{1}$ \\ ${ }^{1}$ Grupo de Oncologia, Disciplina de Gastroenterologia, Universidade Federal de São Paulo, SP, Brasil \\ 2 Departamento de Cirurgia, Santa Casa de Misericórdia de São Paulo, SP, Brasil
}

\begin{abstract}
BACKGROUND: Studies have demonstrated that some polymorphisms in different interleukin genes may increase the risk of cancer. The aim of this study was to investigate the association between the $I L-8$ ( $\mathrm{rs} 4073)-251 \mathrm{~A} / \mathrm{T}$ gene polymorphism and the risk of gastric cancer (GC). PATIENTS AND METHODS: A case-control study was conducted on patients with noncardia gastric cancer. DNA was extracted from leukocytes and the IL-8 (rs4073) -251A/T polymorphism was analyzed by PCR-RFLP. Infection with Helicobacter pylori was investigated in the serum by ELISA. RESULTS: The sample consisted of 104 patients with GC and 196 controls. Cigarette smoking $(P=0.007)$ and high fat intake $(P=0.01)$ were more frequent in patients with GC. The proportion of patients infected with $H$. pylori was similar in the two groups $(P=0.101)$. The frequency of the genotype A/T was higher in the cancer group $(P=0.008)$. An increased risk of $\mathrm{GC}$ was found in subjects carrying the genotype A/T (OR=2.50, CI: 1.27-4.90), subjects with high fat intake (OR=1.92, CI: 1.17-3.15), and smokers (OR=2.00, CI: 1.20 3.31). CONCLUSIONS: Subjects with the heterozygous A/T genotype, high fat intake and smokers or ex-smokers presented an increased risk of GC. Individuals with A/ A genotype may have protective effect for GC.
\end{abstract}

Key words: IL-8, polymorphism, gastric cancer.

\section{INTRODUCTION}

Gastric cancer (GC) is the fourth most common type of cancer in the world and the second leading cause of death due to cancer. In general, the incidence of GC is two to three times greater in developing countries and the frequency of this cancer is higher among men than among women (MatysiakBudnika and Me'graudb, 2006; Ferlay et al., 2007; Wen and Moss 2009; INCA, 2010).

IL-8 is a chemokine produced by macrophages and other cells such as epithelial and endothelial cells (Wolff et al., 1998). This cytokine is involved in the inflammatory response to infection with Helicobacter pylori, recruits phagocytes and causes damage to the gastric mucosa by inducing the release of reactive oxygen radicals (Torok et al., 2005; Ohyauchi et al., 2005). Furthermore, studies have shown that IL-8 induces cell proliferation and angiogenesis (Karashima et al., 2003; Taguchi et al., 2005).

In the early 1990s, Clore et al., (1990) described the three-dimensional structure of IL-8. The locus in the human genome was identified on chromosome 4q21.1. In 2002, IL-8 was renamed CXCL8 by the Chemokine Nomenclature Subcommittee of the International Union of Immunological Societies, although the symbol IL-8 has remained (Bacon et al., 2002).

Several risk factors associated with GC have been identified, including $H$. pylori infection, dietary factors such as salt-preserved foods and dietary nitrite, as well as smoking and alcohol drinking habits (Ladeiras-Lopes et al., 2008; Joossens et al., 1996).

More than $50 \%$ of the world population is infected with this bacterium (Danesh, 1999). Most case-control and cohort studies have shown that the risk of patients with $H$. pylori infection for developing GC is increased from two to six fold (Eslick et al., 1999). Moreover, some of the trials on H. pylori eradication revealed that cure of its infection reduces the development of GC in high risk populations (Wong et al., 2004; Fukase et al., 2008). Accumulated evidence indicates that there are three steps in gastric carcinogenesis: H. pylori infection, development of gastric precancerous conditions and carcinogenesis (Hamajima et al., 2006). Severe gastric atrophy and corpuspredominant gastritis, intestinal metaplasia and dysplasia are well recognized as predominant predispositions to GC (Correa, 1988; Uemura et al., 2001).

Studies have indicated that activation of the transcription factor NF- $\kappa \mathrm{B}$ has a dominant role in H. pylori-induced IL-8 production in gastric epithelial cells. NF- $\kappa \mathrm{B}$ can be activated by phosphorylation via different signaling pathways leading to subsequent proteolytic degradation of I $\kappa$ B. Activated NF$\kappa \mathrm{B}$ translocates to the nucleus where it up-regulates $I L-8$ gene transcription (Crabtree et al., 1995; Yamaoka et al, 2000).

Many investigators have reported associations between single nucleotide polymorphisms (SNPs) in genes that regulate the host's inflammatory response and GC, with sometimes conflicting results. The inflammatory response-related genes that have been most frequently studied in relation to GC are interleukin (IL) genes IL1B, IL1RN, IL-8, and IL10, coding for the proteins IL-1 $\beta$, IL-1ra, IL-8, and IL-10, respectively. These cytokines are important mediators in gastric physiology and pathophysiology and could play important roles in the etiology of GC (Sharma et al., 1998). There is growing interest in identifying the association between IL-8 (rs4073) genotypes and the risk of GC (Ohyauchi et al., 2005; Taguchi et al., 2005; Sarvestani et al., 2006; Shirai et al., 2006 Persson et al., 2011). 
The aim of this study was to determine the frequency of the IL-8 (rs4073) promoter polymorphism (-251A/T) genotypes $\mathrm{A} / \mathrm{A}, \mathrm{A} / \mathrm{T}$ and $\mathrm{T} / \mathrm{T}$ in patients with $\mathrm{GC}$ and to correlate this polymorphism with $H$. pylori infection, consumption of red meat, fat and alcohol and smoking.

\section{PATIENTS AND METHODS}

A case-control study was conducted on patients of both genders with adenocarcinoma of the stomach aged $>18$ years and treated at the Gastroenterology Division of Universidade Federal de Sao Paulo and Santa Casa de Misericordia de Sao Paulo, Brazil. Patients with cancer of the cardia or diffuse-type adenocarcinoma were excluded. The control group consisted of healthy subjects who attended the Central Laboratory of the hospital for blood collection. Patients with cancer were excluded from the control group. The study was approved by the Ethics Committee of the two hospitals and all patients agreed to participate in the study by signing an informed consent form.

All patients filled out a questionnaire on the frequency of food intake, including meat, fat, vegetables, and fruits. Habits such as smoking and alcohol consumption were also recorded and classified as 'never used' and 'current user'.

Serum anti-H. pylori IgG levels were measured by a commercially available kit (R-Biopharm GmbH, Germany) based on the enzyme-linked immunosorbent assay (ELISA) method.

Genotyping procedure: DNA was extracted from peripheral venous blood leukocytes collected with EDTA as anticoagulant using the Set Invisorb ${ }^{\mathrm{TM}}$ (Invisorb, Blood Spin Mini kit, Germany). The samples were submitted to the polymerase chain reaction (PCR) and subsequently genotyped by restriction fragment length polymorphism (RFLP) analysis. The following primers were used: forward primer: 5' - TTCTAACACCTGCCACTCTAG - 3' and reverse: 5' CTGAAGCTCCACAATTTGGTG - 3'. PCR was performed in a final volume of $10 \mu \mathrm{L}$ containing $40 \mathrm{ng}$ DNA, 1x buffer reagent, $0.125 \mathrm{mmol} / \mathrm{L}$ of each deoxynucleotide triphosphate (dNTP), $1.5 \mathrm{mmol} / \mathrm{L} \mathrm{MgCl}_{2}, 0.75 \mathrm{mmol} / \mathrm{L}$ of each primer, and 0.5 units Platinum Taq DNA polymerase. The PCR conditions were denaturation at $94{ }^{\circ} \mathrm{C}$ for $4 \mathrm{~min}$, followed by 35 cycles at $94{ }^{\circ} \mathrm{C}$ for $30 \mathrm{~s}, 60{ }^{\circ} \mathrm{C}$ for $30 \mathrm{~s}$ and $72{ }^{\circ} \mathrm{C}$ for $30 \mathrm{~s}$, with a final extension at $72{ }^{\circ} \mathrm{C}$ for $7 \mathrm{~min}$. After amplification, the PCR products were digested with 5 units of $\mathrm{MfeI}$ for $12 \mathrm{~h}$ at $37^{\circ} \mathrm{C}$. The digestion products were separated by electrophoresis on $5 \%$ agarose gels stained with ethidium bromide (Taguchi et al., 2005). Genome sequencing was used to confirm the PCR and RFLP techniques using random samples of the two groups. The amplicons were purified bywith the Big Dye XTerminator Kit (Applied Biosystems) and sequenced in an ABI Prism 3100 sequencer (Applied Biosystems). The reverse primer was used for sequencing. The electropherogram was analyzed with the Sequence Scanner v1.0 program.

\section{Statistical analysis:}

The data were analyzed using Minitab (Version 15) (Minitab, State College, PA, USA). The Student t-test and $\chi^{2}$ test were used for comparison and odds ratios (OR) and confidence intervals (CI) $(95 \%)$ were calculated using the Cox regression model to examine the impact of the polymorphism on GC risk.
Multivariate logistic regression was applied to identify risk factors. A $P$ value $<0.05$ was considered statistically significant.

\section{RESULTS}

All samples were submitted to genotyping by digestion of the amplicons by RFLP. Subjects carrying the homozygous $\mathrm{T} / \mathrm{T}$ genotype showed a single band of $108 \mathrm{bp}, \mathrm{A} / \mathrm{A}$ homozygotes had two bands of 76 and $32 \mathrm{bp}$, and subjects carrying the heterozygous A/T genotype presented three bands of 108, 76, and $32 \mathrm{bp}$ as shown in Figure 1.

The case group consisted of 104 patients with GC, including $47(45.2 \%)$ women. The control group consisted of 196 subjects, including 107 (54.6\%) women. The patients of the case and control groups were admitted during the same period. There was no difference in gender $(P=0.121)$ or age $(P=0.117)$ between the groups. Lifestyle analysis showed no significant differences between the control and case groups in terms of the consumption of alcohol $(P=0.391)$, fruits $(P=0.809)$, vegetables $(P=0.340)$, cereals $(P=0.167)$, or red meat $(P=0.499)$. There was a relationship between smoking and GC; nearly $61 \%$ of GC patients were current smokers plus former smokers (those who had smoked in some period during the past year), statistically different $(P=0.007)$ than the control group $(57.6 \%)$ who never smoked. The GC patients consumed significantly $(P=0.005)$ more fat foods $(48.1 \%)$ compared to the control group $(31.6 \%)$. There was no statistically significant difference between GC and persons with $H$. pylori positivity IgG antibody, which was detected in $45.2 \%$ of the GC patients vs. $54.6 \%$ of the controls $(P=0.101)$. The frequencies of the $\mathrm{A} / \mathrm{A}, \mathrm{A} / \mathrm{T}$ and $\mathrm{T} / \mathrm{T}$ genotypes were $26.5 \%, 43.4 \%$ and $30.1 \%$, respectively, in the control group, and $14.4 \%, 55.8 \%$ and $29.8 \%$ in the case group. The genotypic distribution is in Hardy-Weinberg equilibrium in the control group $(p>0.05)$. The frequency of the genotypes differed between the two groups $\left(\chi^{2}=6.654, P=0.036\right)$, and on the other hand, there was no statistical difference in allele frequency

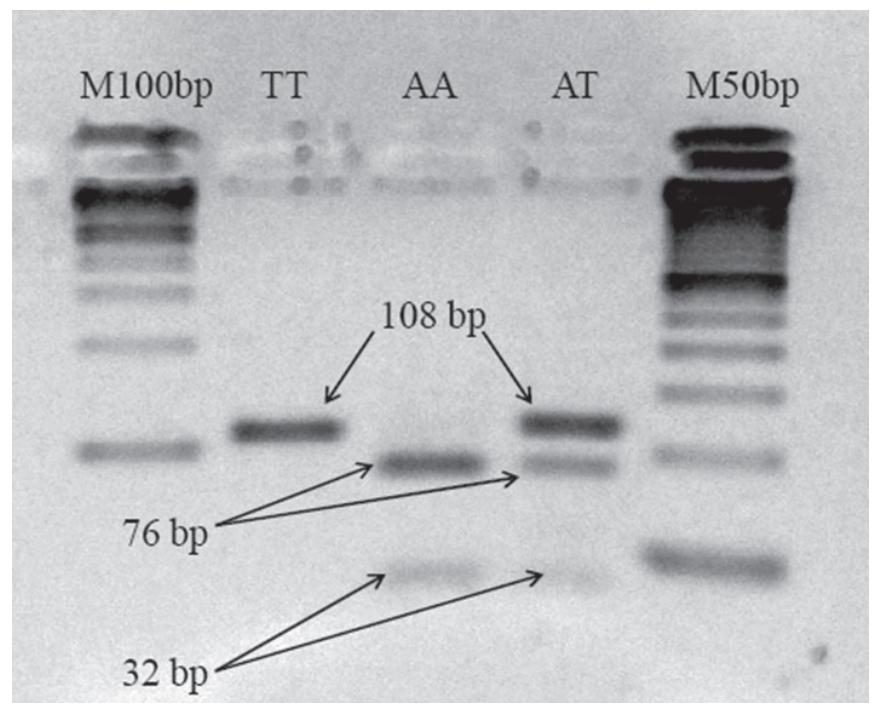

Figure 1. Subjects carrying the homozygous TT genotype showed a single band of 108 base pairs (bp), AA homozygotes had two bands of 76 and $32 \mathrm{bp}$, and subjects carrying the heterozygous AT genotype presented three bands of 108, 76, and $32 \mathrm{bp}$. DNA Molecular Weight Marker (100 bp ladder). 
between groups $\left(\chi^{2}=1.677, P=0.631\right)$. Comparing GC patients with $\mathrm{T} / \mathrm{T}$ genotype to the subgroup with $\mathrm{A} / \mathrm{T}+\mathrm{A} / \mathrm{A}$ genotypes did not show a significant difference from the control group $(P=0.866)$. However, comparing the sub group with $\mathrm{A} / \mathrm{A}$ genotypes vs. A/T+T/T genotypes, there was a significant difference compared to the controls $(P=0.003)$. The proportion of GC patients was significantly greater in the T carriers (A/ $\mathrm{T}+\mathrm{T} / \mathrm{T})$ than in the non-T carriers $(\mathrm{A} / \mathrm{A})(P=0.015)$. Although a positive association was observed among individuals for the $\mathrm{A} / \mathrm{T}$ genotype and GC (OR $=2.50, \mathrm{CI} 1.27-4.90, P=0.008)$, and among $\mathrm{T} / \mathrm{T}$ genotype vs. A/A genotype and GC, the results were not statistically significant $(P=0.106)$. Individuals with
A / A genotype had a significantly lower risk of $\mathrm{GC}(\mathrm{OR}=0.45$, CI $0.24-0.86, P=0.003)$ compared to $(\mathrm{A} / \mathrm{T}+\mathrm{T} / \mathrm{T})$ genotypes. The $\mathrm{T}$ allele was not statistically significantly associated with CG risk $(P=0.631)$; however, $\mathrm{T}$ carriers was associated with an increased risk of GC (OR $=2.21$, CI 1.17-4.20, $P=0.015)$. These results remained consistent for IL-8 (rs4073) genotypes associated with GC in unadjusted and age-sex adjusted models, which are presented in Table 1.

In multivariate logistic regression analysis adjusted for age and sex, the following factors were associated with high risk of GC in Current + Ex-smokers $(P=0.030$; OR:1.79, 95\% CI $=1.06-$ 3.01), high-fat diet ( $P=0.047$; OR:1.66, 95\% CI $=1.02-2.95)$, and

TABLE 1

Characteristics of the study population. Odds ratios (OR) for gastric cancer according to Cigarette smoking, Fat intake, $H$. pylori infection, Genotype and Alleles frequencies, T Carriers using case-control data

\begin{tabular}{|c|c|c|c|c|c|c|}
\hline Variable & $\begin{array}{c}\text { Cases } \\
\mathrm{N}=104\end{array}$ & $\begin{array}{l}\text { Controls } \\
\mathrm{N}=196 \\
\end{array}$ & $\mathrm{P}$ & $\mathrm{OR}^{*}(95 \% \mathrm{CI})$ & $P$ & $\mathrm{OR}^{* *}(95 \% \mathrm{CI})$ \\
\hline Gender & $\begin{array}{ccc}\mathrm{N}(\%) & \mathrm{N} \\
(\%) & \end{array}$ & $\mathrm{N}(\%)$ & & & & \\
\hline Male & $57(54.8)$ & $89(45.4)$ & 0.121 & - & & - \\
\hline Female & $47(45.2)$ & $107(54.6)$ & & & & \\
\hline \multicolumn{7}{|l|}{ Age } \\
\hline Male & $59.9 \pm 14.4$ & $64.0 \pm 10.3$ & $0.117^{\#}$ & - & & - \\
\hline Female & $60.4 \pm 11.6$ & $62.0 \pm 14.0$ & & & & \\
\hline Total & $60.7 \pm 11.8$ & $63.0 \pm 12.4$ & & & & \\
\hline \multicolumn{7}{|l|}{ Smoker } \\
\hline Never & $40(38.5)$ & $113(57.6)$ & & 1.00 Reference & & 1.00 Reference \\
\hline Current +Ex-Smokers & $64(61.5)$ & $83(42.4)$ & 0.007 & $2.00(1.20-3.31)$ & 0.002 & $2.18(1.34-3.54)$ \\
\hline \multicolumn{7}{|l|}{ Fat Intake } \\
\hline Low $^{1}$ & $54(51.9)$ & $134(68.4)$ & & 1.00 Reference & & 1.00 Reference \\
\hline High $^{2}$ & $50(48.1)$ & $62(31.6)$ & 0.010 & $1.92(1.17-3.15)$ & 0.005 & $2.00(1.23-3.26)$ \\
\hline \multicolumn{7}{|l|}{ H pylori infection } \\
\hline Negative & $57(54.8)$ & $89(45.4)$ & & 1.00 Reference & & 1.00 Reference \\
\hline Positive & $47(45.2)$ & $107(54.6)$ & 0.101 & $0.71(0.44-1.15)$ & 0.121 & $0.69(0.43-1.11)$ \\
\hline \multicolumn{7}{|l|}{ Genotypes } \\
\hline $\mathrm{A} / \mathrm{A}$ & $15(14.4)$ & $52(26.5)$ & $0.036^{+}$ & 1.00 Reference & & 1.00 Reference \\
\hline $\mathrm{A} / \mathrm{T}$ & $58(55.8)$ & $85(43.4)$ & 0.008 & $2.50(1.27-4.90)$ & 0.005 & $2.37(1.22-4.60)$ \\
\hline $\mathrm{T} / \mathrm{T}$ & $31(29.8)$ & $59(30.1)$ & 0.106 & $1.83(0.88-3.79)$ & 0.143 & $1.82(0.89-3.74)$ \\
\hline A Allele & $88(43.3)$ & $189(48.2)$ & & 1.00 Reference & & 1.00 Reference \\
\hline T Allele & $120(57.7)$ & $203(51.8)$ & 0.631 & $1.09(0.76-1.56)$ & 0.195 & $1.27(0.90-1.78)$ \\
\hline $\mathrm{A} / \mathrm{T}+\mathrm{A} / \mathrm{A}$ & $73(70.2)$ & 137 (69.9) & & 1.00 Reference & & 1.00 Reference \\
\hline $\mathrm{T} / \mathrm{T}$ & $31(29.8)$ & $59(30.1)$ & 0.866 & $0.96(0.56-1.62)$ & 0.958 & $0.99(0.59-1.66)$ \\
\hline $\mathrm{A} / \mathrm{T}+\mathrm{T} / \mathrm{T}$ & $89(85.6)$ & $144(73.5)$ & & 1.00 Reference & & 1.00 Reference \\
\hline $\mathrm{A} / \mathrm{A}$ & $15(14.4)$ & $52(26.5)$ & 0.003 & $0.45(0.24-0.86)$ & 0.014 & $0.47(0.25-0.88)$ \\
\hline No T Carriers & $15(14.4)$ & $52(26.5)$ & & & & \\
\hline T Carriers & $89(85.6)$ & $144(73.5)$ & 0.015 & $2.21(1.17-4.20)$ & 0.017 & $2.14(1.14-4.03)$ \\
\hline
\end{tabular}

Values are means \pm standard deviation for continuous variables and $\mathrm{n}(\%)$ for categorical variables. Low ${ }^{1}$ : almost never, 3-4 times/mo; ${ }^{2}$ High: $3-4$ times/wk, more than once/d. $P$ for trend Pearson Chi-Square $\left(c^{2}\right)$ test; ${ }^{*}$ Two-Sample T-Test. ${ }^{*}$ OR (Odds Ratios) and $\mathrm{Cl}$ (Confidence interval) adjusted by age and sex. ${ }^{* *}$ Unadjusted; ${ }^{+} P$ for Genotypes trend. 
A/T genotype individuals $(P=0.014$; OR: $2.36,95 \% \mathrm{CI}=1.19$ 4.67) as shown in Table 2.

Figure 2 shows the survival estimated by Kaplan-Meier analysis and comparison of curves by log-rank test; our study showed no difference between the probability of survival of GC patients and IL-8 (rs4073) polymorphism ( $P=0.038$ ). CG patients with advanced stage were significantly associated $(P=0.003)$ with decreased survival.

\section{DISCUSSION}

Gastric cancer is the fourth most common cancer and the second cause of death from cancer worldwide (Crew et al., 2006; Jemal et al., 2008). Data from the Brazilian National Cancer Institute (INCA) show that GC is more frequent among men $(64.3 \%)$, with a higher incidence in patients over the age of

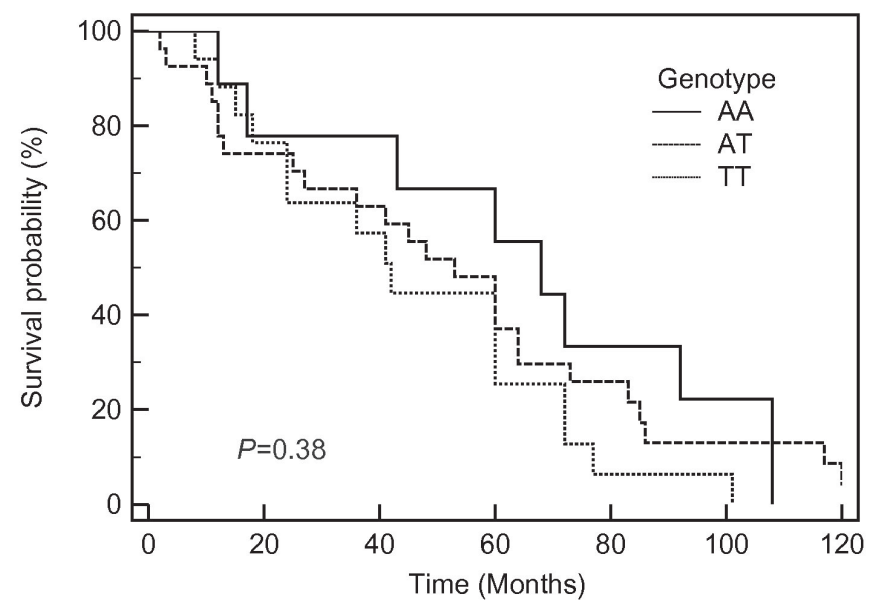

Figure 2. Kaplan-Meier survival plot for gastric cancer patients by interleukin-8 genotype. Survival was estimated Kaplan-Meier analysis and comparison of curves by long-rank test, our study showed no difference between the probability of survival of GC patients and IL-8 polymorphism.
50 in both genders (INCA, 2010). A higher prevalence among men $(54.8 \%)$ was also observed in the present study, with the mean age being 60.7 years in the two genders.

Studying patients from Nagoya, Japan, Shirai et al. (2006) demonstrated an association between GC and infection with $H$. pylori, with a higher rate of infection being observed among patients with GC $(91.1 \%)$ compared to those without cancer $(58.8 \%)$. In the present study, no significant difference in the proportion of patients infected H. pylori was diagnosed $(P=0.101)$. Similarly, Lu et al. found no increased frequency of patients infected with $H$. pylori in the cancer group $(P=0.18)(\mathrm{Lu}$ et al., 2005).

The occurrence of GC has also been associated with exposure to intrinsic (genetic) and extrinsic factors, such as the consumption of diets containing high concentrations of sodium chloride, nitrates and nitrites found in smoked foods, sausages and potato chips (Teixeira and Nogueira, 2003). In the present study, no significant differences in dietary habits (consumption of fruits, cereals, red meat, and vegetables) were observed for patients with GC. However, the consumption of fried foods and fats was significantly greater among cancer patients compared to subjects without cancer.

Epidemiological studies have demonstrated a relationship between nutrition and GC, with the observation of a protective effect of diets containing fresh vegetables and fruits, probably due to the presence of vitamin $\mathrm{C}$ and carotene which reduce the risk of cancer (Kono and Hirohata, 1996; Latorre, 1997). However, this relationship was not observed in the present study, possibly because of the difficulty in measuring the intake of these foods throughout life. A food frequency questionnaire on the consumption of certain foods and beverages was applied to the subjects to evaluate the relationship between diet and disease (Salvo and Gimeno, 2002). In a multicenter study involving 10 European countries, Buckland et al. (2010) found a significant reduction in the risk of GC in countries where adherence to the Mediterranean diet was greater.

The $-251 \mathrm{~A} / \mathrm{T}$ polymorphism in the promoter region of the IL-8 (rs4073) gene has been the target of studies investigating which genetic profile is associated with a higher risk of or

TABLE 2

Multivariate logistic regression analysis stratified by the selected variables

\begin{tabular}{|c|c|c|c|c|}
\hline Variable & $\begin{array}{c}\text { Cases } \\
\mathrm{N}=104 \\
\end{array}$ & $\begin{array}{l}\text { Controls } \\
\mathrm{N}=196 \\
\end{array}$ & $P$ & $\begin{array}{c}\mathrm{OR}^{*} \\
(95 \% \mathrm{CI}) \\
\end{array}$ \\
\hline \multicolumn{5}{|l|}{ Smoker } \\
\hline Never & $40(38.5)$ & $113(57.6)$ & & 1.00 Reference \\
\hline Smokers** & $64(61.5)$ & $83(42.4)$ & 0.030 & $1.79(1.06-3.01)$ \\
\hline \multicolumn{5}{|l|}{ Fat Intake } \\
\hline Low $^{1}$ & $54(51.9)$ & $134(68.4)$ & & 1.00 Reference \\
\hline $\mathrm{High}^{2}$ & $50(48.1)$ & $62(31.6)$ & 0.047 & $1.66(1.02-2.95)$ \\
\hline \multicolumn{5}{|l|}{ Genotypes } \\
\hline $\mathrm{A} / \mathrm{A}$ & $15(14.4)$ & $52(26.5)$ & & 1.00 Reference \\
\hline $\mathrm{A} / \mathrm{T}$ & $58(55.8)$ & $85(43.4)$ & 0.014 & $2.36(1.19-4.67)$ \\
\hline $\mathrm{T} / \mathrm{T}$ & $31(29.8)$ & $59(30.1)$ & 0.130 & $1.78(0.84-3.74)$ \\
\hline
\end{tabular}

Low': almost never, 3-4 times/mo; ${ }^{2}$ High: 3-4 times/wk, more than once/d; $P$ for trend; *OR (Odds Ratios) and $\mathrm{Cl}$ (Confidence interval) adjusted by age and sex; **Current Smokers + Ex-Smokers. 
protection against gastrointestinal disease. In a recent study, Song et al. (2010) found a significant association between the IL-8 (rs4073) polymorphism and cachexia in GC patients (OR=1.765, 95\% CI: 1.192-2.615; $P=0.004)$. However, the number of cases and controls was relatively small in that study. A Polish study reported no association between GC and the $-251 \mathrm{~A} / \mathrm{T}$ polymorphism (Savage et al., 2006). However in another case-control study, Japanese investigators found no significant difference in genotype $(P=0.95)$ or allele $(P=0.93)$ frequencies of the IL-8 (rs4073) polymorphism (Shirai et al., 2006). Similar results have been also reported by Kamangar et al. (2006) in Finland $(P=0.82)$ who also studied the IL-8 (rs4073) polymorphism (OR=0.92, 95\% CI: 0.42-2.00). Sarvestani et al. (2006) studied Iranian patients with GC, and observed a higher frequency of genotype $\mathrm{T} / \mathrm{T}(P=0.04)$ and a marginal difference $(P=0.07)$ in the frequency of allele T between patients $(62 \%)$ and controls (56\%). Similarly, Lee et al. (2005) found a higher frequency of genotype $\mathrm{T} / \mathrm{T}$ in Chinese patients with GC ( $P=0.002$ ), with $90 \%$ of these patients showing an increased risk of this malignancy (OR=1.93, 95\% CI: 1.26-2.95). These authors also reported a significant difference $(P=0.004)$ in $\mathrm{T}$ allele proportion between the cancer group $(64.8 \%)$ and the control group $(57.5 \%)$. No association between allele frequency and the risk of GC was observed in our study.

In contrast, a study conducted in Mexico showed that the IL-8 (rs4073) -251A allele is a risk factor for the development of noncardia GC (Garza-Gonzalez et al., 2007). In China, Lu et al. (2005) observed a greater risk of GC in subjects with genotype $\mathrm{A} / \mathrm{A}$ and $H$. pylori infection $(\mathrm{OR}=2.54,95 \% \mathrm{CI}$ : 1.38 4.72; $P=0.012$ ). In the study of Taguchi et al. (2005), the A/A genotype was found to be strongly associated with gastric carcinogenesis compared to genotype $\mathrm{T} / \mathrm{T}$ in Japanese patients (OR=2.22, 95\% CI: 1.08-4.56; $P=0.03$ ).

In the present study, the individuals with homozygous A / A genotype may have a protective effect on CG (OR=0.45, 95\% CI: $0.24-0.86 ; P=0.003)$. The heterozygous $\mathrm{A} / \mathrm{T}$ genotype increased more than twice the risk of $\mathrm{GC}(\mathrm{OR}=2.50,95 \% \mathrm{CI}$ : 1.27-4.90; $P=0.008)$. Similar results have been reported by Ohyauchi et al., (2005) who showed that this genotype was more frequent in patients with GC $(\mathrm{OR}=2.02,95 \% \mathrm{CI}$ : 1.37-2.97; $P=0.0005)$.

Sarvestani et al. (2006) also compared the frequency of IL-8 (rs4073) genotypes between patients with gastritis, peptic ulcer and GC and found a higher prevalence of the A/A genotype in patients with GC compared to those with benign diseases $(P=0.013)$. These differences in genotypes may be due to differences in ethnic groups and disease etiology and/or sample size limitations.

We compared the IL-8 (rs4073) polymorphism with survival time in 104 patients with GC. The median survival time was 68 months for patients with the IL-8 (rs4073) -251A/A genotype, 53 months for patients with the A/T genotype, and 42 months for patients with the T/T genotype. The IL-8 (rs4073) -251 genotypes were not associated with the prognosis of GC $(P=0.38, \log$-rank test). By contrast, Lurje et al. (2010) found a significant result $(\mathrm{P}<0.001)$ between the probability of survival of GC patients and $I L-8$ (rs4073) polymorphism, and they found the A/A genotype associated with increased survival. The limitation of the study was the relatively small sample size, which limits the generality of the results.

In conclusion, the presence of the $\mathrm{A} / \mathrm{T}$ genotype was associated with an increased risk of GC in the population studied. Individuals with A / A genotype may have protective effect on GC. No association was observed between allele frequency and the risk of GC. Subjects consuming large amounts of fried foods and ex-smokers/smokers are at higher risk of GC.

\section{ACKNOWLEDGEMENTS}

We would like to thank the Research Support Foundation of the State of Sao Paulo (FAPESP) for funding this study. We also would like to thank Juliana Oliveira for her support during the revision of the manuscript.

\section{FOOTNOTES}

Supported by The São Paulo Research Foundation (FAPESP), Oncology Group - Gastroenterology Division, Universidade Federal de São Paulo, São Paulo, Brazil

\section{REFERENCES}

BACON K, BAGGIOLINI $M$, BROXMEYER $H$, HORUK $R$, LINDLEY I, MANTOVANI A, MAYSUSHIMA K, MURPHY P, NOMIYAMA H, OPPENHEIM J, ROT A, SCHALL T, TSANG M, THORPE R, VAN DAMME J, WADHWA M, YOSHIE O, ZLOTNIK A, ZOON K (2002) Chemokine/chemokine receptor nomenclature. J Interferon Cytokine Res 10:1067-1068.

BRASIL (2010) Ministério da Saúde. Instituto Nacional do Câncer (INCA): Data base: http:/ / www1.inca.gov.br/estimativa /2010/ Accessed: July, 2010.

BUCKLAND G, BACH A, SERRA-MAJEM L (2010) Adherence to a Mediterranean diet and risk of gastric adenocarcinoma within the European Prospective Investigation into Cancer and Nutrition (EPIC) cohort study. Am J Clin Nutr 91:381-390.

CLORE GM, APPELLA E, YAMADA M, MA/TSUSHIMA K, GRONENBORN AM (1990) Three-dimensional structure of interleukin 8 in solution. Biochemistry. 29:1689-96.

CORREA P (1988) A human model of gastric carcinogenesis. Cancer Res 48:3554-3560.

CRABTREE JE, XIANG Z, LINDLEY IJ, TOMPKINS DS, RAPPUOLI R, COVACCI A (1995) Induction of interleukin-8 secretion from gastric epithelial cells by a cagA negative isogenic mutant of Helicobacter pylori. J Clin Pathol 48:967-969.

CREW KD, NEUGUT AI (2006) Epidemiology of gastric cancer. World J Gastroenterol 12:354-362.

DANESH J (1999) Helicobacter pylori infection and gastric cancer: systematic review of the epidemiological studies. Aliment Pharmacol Ther 13:851856.

ESLICK GD, LIM LL, BYLES JE, XIA HH, TALLEY NJ (1999) Association of Helicobacter pylori infection with gastric carcinoma: a meta-analysis. Am J Gastroenterol 94:2373-2379.

FERLAY J,AUTIER P, BONIOL M, HEANUE M, COLOMBET M, BOYLE P (2007) Estimates of the cancer incidence and mortality in Europe in 2006. Ann Oncol 18:581-592.

FUKASE K, KA/TO M, KIKUCHI S, INOUE K, UEMURA N, OKAMOTO S, TERAO S, AMAGAI K, HAYASHI S, ASAKA M (2008) Effect of eradication of Helicobacter pylori on incidence of metachronous gastric carcinoma after endoscopic resection of early gastric cancer: an openlabel, randomised controlled trial. Lancet. 372:392-397.

GARZA-GONZÁLEZ E, BOSQUES-PADILLA FJ, MENDOZA-IBARRA SI, FLORES-GUTIÉRREZ JP, MALDONADO-GARZA HJ, PÉREZ-PÉREZ GI (2007) Assessment of the toll-like receptor 4 Asp299Gly, Thr399Ile and interleukin-8 -251 polymorphisms in the risk for the development of distal gastric cancer. BMC Cancer 26:70.

HAMAJIMA N, NAITO M, KONDO T, GOTO Y (2006) Genetic factors involved in the development of Helicobacter pylori-related gastric cancer. Cancer Sci 97:1129-1138

JEMAL A, SIEGEL R, WARD E, HAO Y, XU J, MURRAY T, THUN MJ (2008) Cancer statistics, 2008. CA Cancer J Clin 58:71-96.

JOOSSENS JV, HILL MJ, ELLIOTT P, STAMLER R, LESAFFRE E, DYER A, NICHOLS R, KESTELOOT H. (1996) Dietary salt, nitrate and stomach 
cancer mortality in 24 countries. European Cancer Prevention (ECP) and the INTERSALT Cooperative Research Group. Int J Epidemiol 25:494-504.

KAMANGAR F, ABNET CC, HUTCHINSON AA, NEWSCHAFFER CJ, HELZLSOUER K, SHUGART YY, PIETINEN P, DAWSEY SM, ALBANES D, VIRTAMO J, TAYLOR PR (2006) Polymorphisms in inflammationrelated genes and risk of gastric cancer (Finland). Cancer Causes Control. 17:117-125.

KARASHIMA T, SWEENEY P, KAMAT A, HUANG S, KIM S J, BAR-ELI M, MCCONKEY D J, DINNEY C P N. (2003) Nuclear Factor-B Mediates Angiogenesis and Metastasis of Human Bladder Cancer through the Regulation of Interleukin-8. Clinical Cancer Research. 9:2786-2797.

KONO S, HIROHA/TA T (1996) Nutrition and stomach cancer. Cancer causes control 7:41-55.

LADEIRAS-LOPES R, PEREIRA AK, NOGUEIRA A, PINHEIRO-TORRES T, PINTO I, SANTOS-PEREIRA R, LUNET N (2008) Smoking and gastric cancer: systematic review and meta-analysis of cohort studies. Cancer Causes Control 19:689-701.

LA/TORRE MD (1997) Stomach cancer mortality in Brazil: from 1977 to 1989. Cad Saude Publica. 13:67-78.

LEE W P, TAI D I, LAN K H, LI A F Y, HSU H C, LIN E J, LIN Y P, SHEU M L, LI C P, CHANG F Y, CHAO Y, YEN S H, LEE S D (2005) The -251T allele of the Interleukin-8 Promoter Is Associated with Increased Risk of Gastric Carcinoma Featuring Diffuse-Type Histopathology in Chinese Population. Clin Cancer Research 11:6431-6441.

LU W, PAN K, ZHANG L, LIN D, MIAO X, YOU W (2005) Genetic polymorphisms of interleukin (IL)-1B, IL-1RN, IL-8, IL-10 and tumor necrosis factor a and risk of gastric cancer in a Chinese population. Carcinogenesis 26:631-636.

LURJE G, HUSAIN H, POWER DG, YANG D, GROSHEN S, POHL A, ZHANG W, NING Y, MANEGOLD PC, EL-KHOUEIRY A, IQBAL S, TANG LH, SHAH MA, LENZ HJ (2010) Genetic variations in angiogenesis pathway genes associated with clinical outcome in localized gastric adenocarcinoma. Ann Oncol 21:78-86.

MATYSIAK-BUDNIKA T, ME'GRAUDB F (2006) H. pylori infection and gastric cancer. European Journal of Cancer 42:708-716.

OHYAUCHI M, IMA/TANI A, YONECHI M, ASANO N, MIURA A, IIJIMA K, KOIKE T, SEKINE H, OHARA S, SHIMOSEGAWA T (2005) The polymorphism interleukin $8-251 \mathrm{~A} / \mathrm{T}$ influences the susceptibility of $H$. pylori related gastric diseases in the Japanese population. GUT 5:330-335.

PERSSON C, CANEDO P, MACHADO JC, EL-OMAR EM, FORMAN D (2011) Polymorphisms in inflammatory response genes and their association with gastric cancer: A HuGE systematic review and metaanalyses. Am J Epidemiol 173:259-270.

SALVO VL, GIMENO SG (2002) Reproducibility and validity of a food frequency questionnaire. Rev Saude Publica 36:505-512.

SARVESTANI E K, BAZARGANI A, MASOUDIAN M, LANKARANI K, TAGHAVI AR, SABERIFIROOZI M (2006) Association of H pylori cagA and vacA genotypes and IL-8 (rs4073) gene polymorphisms with clinical outcome of infection in Iranian patients with gastrointestinal diseases World J Gastroenterol 12:5205-5210.

SAVAGE SA, HOU L, LISSOWSKA J, CHOW WH, ZA/TONSKI W, CHANOCK SJ, YEAGER M (2006) Interleukin-8 Polymorphisms Are Not Associated with Gastric Cancer Risk in a Polish Population. Cancer Epidemiol Biomarkers Prev 15: 589-591.

SHARMA SA, TUMMURU MK, BLASER MJ, KERR LD (1998) Activation of IL-8 gene expression by Helicobacter pylori is regulated by transcription factor nuclear factor-kappa B in gastric epithelial cells. J Immunol 160:2401-2407.

SHIRAI K, OHMIYA N, TAGUCHI A, MABUCHI N, YA/TSUYA H, ITOH A, HIROOKA Y, NIWA Y, MORI N, GOTO H (2006) Interleukin-8 gene polymorphism associated with susceptibility to non-cardia gastric carcinoma with microsatellite instability. Journal of Gastroenterology and Hepatology 21:1129-1135.

SONG BO, ZHANG DIANLIANG, ZHENG HONGME, WANG XINXIANG, ZHOU YANBING, LIU XIAOBO (2010) Association of interleukin-8 gene polymorphism with cachexia from patients with gastric cancer. J Interferon Cytokine Res 30:9-14.

TAGUCHI A, OHMIYA N, SHIRAI K, MABUCHI N, ITOH A, HIROOKA Y, NIWA Y, GOTO H (2005) Interleukin-8 Promoter Polymorphism Increases the Risk of Atrophic Gastritis and Gastric Cancer in Japan. Cancer Epidemiol Biomarkers Prev 14:2478-2493.

TEIXEIRA JBA, NOGUEIRA MS. (2003) Gastric cancer: risk factors in patients treated in tertiary care services of a municipality in the interior of the state of Sao Paulo. Rev Latino-am Enfermagem 11:43-48.

TOROK AM, BOUTON AH, GOLDBERG JB (2005) H. pylori Induces Interleukin-8 Secretion by Toll-Like Receptor 2 and Toll-Like Receptor 5-Dependent and - Independent Pathways. Infection and Immunity 73:1523-1531.

UEMURA N, OKAMOTO S, YAMAMOTO S, MATSUMURA N YAMAGUCHI S, YAMAKIDO M, TANIYAMA K, SASAKI N, SCHLEMPER RJ (2001) Helicobacter pylori infection and the development of gastric cancer. N Engl J Med 345:784-789.

WEN S, MOSS SF (2009) H. pylori virulence factors in gastric carcinogenesis. Cancer Lett 282:1-8.

WOLFF B, BURNS AR, MIDDLETON J, ROT A (1998) Endothelial Cell "Memory" of Inflammatory Stimulation: Human Venular Endothelial Cells Store Interleukin 8 in Weibel-Palade Bodies. J. Exp. Med 188:1757 1762.

WONG BC, LAM SK, WONG WM, CHEN JS, ZHENG TT, FENG RE, LAI KC, HU WH, YUEN ST, LEUNG SY, FONG DY, HO J, CHING CK, CHEN JS (2004) Helicobacter pylori eradication to prevent gastric cancer in a high-risk region of China: a randomized controlled trial. JAMA 291:187-194.

YAMAOKA Y, KWON DH, GRAHAM DY (2000) A M(r) 34,000 proinflammatory outer membrane protein (oipA) of Helicobacter pylori. Proc Natl Acad Sci USA 97:7533-7538. 